
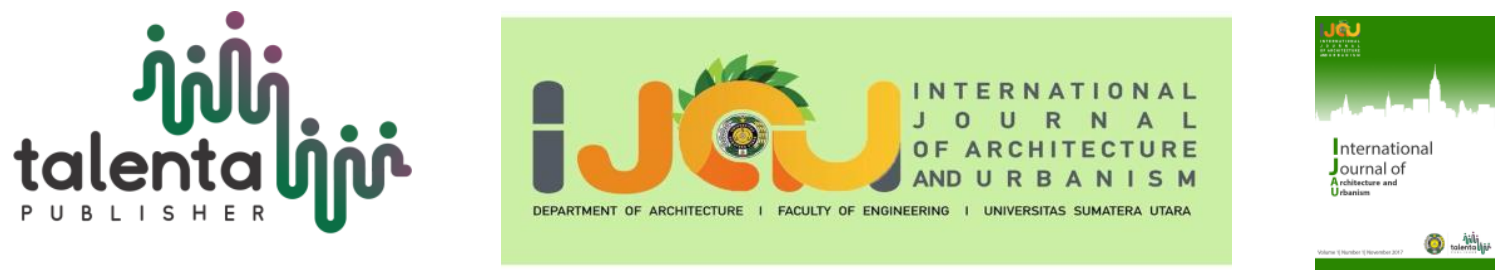

\title{
Seasonal Tourism in Pangururan District, Samosir Regency, Indonesia
}

\author{
Abi Bhisry Siregar ${ }^{1 *}$ \\ ${ }^{1}$ Indonesian architects association, North Sumatera, Medan
}

\begin{abstract}
Indonesia has a variety of tribes and cultures that cannot be separated from the natural beauty which is a tourist destination for the beauty of Lake Toba in North Sumatra. Pangururan District, Samosir Regency is one of the priority points of tourists because Pangururan District is the capital of Samosir Regency so that the impact of the influence of tourist destinations becomes a strategic area for national and international tourism. A person's fatigue in carrying out daily activities makes travelling one of the solutions to calm the mind after facing someone's busy life. Tourism has categories according to conditions, one of which is tourism. Tourism is defined as a form of sustainable tourist visits, in terms of attracting local and non-local tourists with the condition of a tourist destination provided with the natural beauty of Pangururan District, Samosir Regency. Tourism that occurs with tourist visits based on the holiday season and weekdays on tourist visits has increased during holidays with a high number compared to normal days. Tourism management still provides the best service so that tourists don't just drink. In this case, tourism shows the condition of tourists who visit during the holiday season so that they get a response so that the improvement of tourism management is better, this is evidenced by showing the results of field observations. With regard to tourism, it shows that the results are processed based on the opinion of the community as both visitors and local people
\end{abstract}

Keyword: district Pangururan, Samosir, seasonal tourism

Received 15-3-2021|Revised 20-3-2021 | Accepted 31-3-2021

\section{Introduction}

Tourism is one of the factors that can support an area with its search for the area from a social and economic perspective. an area underdeveloped has a significant natural potential for tourist attraction and can be developed as a potential sustainable tourist destination [1] [9]. Continuous tourism visits sustainable tourists every week, month and yearly. There are several times that the increase in tourist visits take place each year. This manager can provide services as a form of attracting visitors at any time so as to maintain the quality of tourist destinations. The better the quality provided, the more visitors will increase in the vulnerability of a sustainable time so as to provide foreign exchange for the region and tourism management [2]. The tourism manager

\footnotetext{
*Corresponding author at:Indonesian architects association, Medan

E-mail address: abisregar13@gmail.com
} 
must be able to provide the best service in running the tourism industry in terms of supporting tourist destinations that are good infrastructure, security, comfort and management so that visitors are not only in certain situations but every time and provide income that is not on time.

Tourism occurs with tourist visits based on holidays and on weekdays this happens to tourist visits which increase on holidays with a high number compared to usual days [11]. The handling of tourism also has an impact on people's income, in this case, many people are at the stage at tourist sites that are managed by individuals or groups [10] [14]. The tourist destinations that are presented provide natural beauty that is located in mountainous areas and lakeside areas in the Lake Toba area, one of which is in Pangururan District, Samosir Regency and makes it one of the national tourism strategy areas managed by the regional government specifically in the Lake Toba area [3].

\section{Literature Review}

\section{Seasonal Tourism}

Tourism is one of the strategic sectors in the Samosir Regency. Apart from being a locomotive for the improvement of the people's economy, this sector also contributes to Regional Original Income (PAD). The amount of contribution to the tourism sector depends on the number of tourist visits to Pangururan District, Samosir Regency [4]. Seasonal tourism is an important issue that needs attention, where the movement of the number of tourist visitors in the high season and the low season will be different [5]. This has an impact on the income of tourism business actors and workers who in the low season will lose their jobs. Monitoring on seasonal tourism issues is very useful for the sustainability of tourism in Pangururan District, Samosir Regency so that from these results it can be used as an evaluation for problem solvers related to the movement of tourist visits to Pangururan District, Samosir Regency and increasing job opportunities in tourist objects.

\section{Seasonal Tourism Research Approach}

The series of data collection on seasonal tourism issues in Pangururan Subdistrict, Samosir Regency, requires data related to components measuring seasonal degrees, components strengthening spring-peak and low tourism, infrastructure components as well as short-term and seasonal employment components [12] [13]. Identification of data regarding components measuring the degree of seasonality, strengthening spring-peak, provision of infrastructure, as well as short-term and seasonal work components, are monitored through secondary data from the tourism office of Samosir Regency [6]. Secondary data on measuring the degree of seasonality, strengthening spring-peak, provision of infrastructure as well as short-term and seasonal work components are components related to the notification to PHRI, government and tourist information centres. The results of annual percentage calculations from measuring the degree of seasonality, strengthening spring-peak, provision of infrastructure and short-term and 
seasonal work components to PHRI, government and tourist information centres in existing conditions are linked to the previous year's calculation results using the Performance Indicator formula [7]. The results of calculations using this formula are linked to the target percentage for achieving the Sustainable Tourism Index (IPBK). The statistical results using this Performance Indicator formula will be interpreted as a factual assessment of seasonal tourism monitoring of tourism activities in Pangururan District, Samosir Regency. Likewise, the component measuring the degree of seasonality, strengthening spring-peak, and the infrastructure provision component, there are several indicators in it which are managed by a qualitative method through area observation. The results of these observations are to support secondary data and primary data. Then for the component to strengthen the spring-peak and low tourism resources, there are several indicators that use quantitative methods by making a table of the number of tourist visits and the number of accommodation occupancy in Pangururan District, Samosir Regency. To fill in the table, it is monitored through secondary data from the tourism office of Samosir Regency.

\section{Methodology}

This study explains the opinions of people who live in tourist sites, both local and non-local, in the tourism discussion on tourism activities, which is located in Pangururan District, Samosir Regency, Indonesia. The method used in this research is a mixture of qualitative and quantitative methods. Qualitative methods by analyzing statistical data and descriptive interviews. The Method through linkert scale and proportion analysis. Data collection was carried out by distributing questionnaires. The questionnaire survey contains questions that are used as a research instrument to determine community perceptions related to tourism in tourism activities in Pangururan District, Samosir Regency. The criteria for respondents who will monitor their responses are local communities and visitors who are in the tourist sites of Pangururan District, Samosir Regency, who have lived more than 18 years of age. The sample for tourism management using a questionnaire consisting of 100 respondents.

The research methodology with regard to the issue of seasonal tourism in Pangururan District, Samosir Regency, is an activity of careful observation of data regarding the level of tourist visits, which is expected to be a solution in dealing with seasonal tourism in Pangururan District, Samosir Regency. The secondary data obtained is in the form of data on tourist visit rates, infrastructure that supports tourism, and data on the number of workers related to notifications to the Tourism Office, the Investment Service and One-Stop Integrated Licensing Service (DPMPPTSP), Information Center, Manpower Office, Cooperatives. , and Trade (Disnaker), Housing and Settlement Areas (Dinas PKP), Public Works Service (Dinas PU). and the Central Statistics Agency (BPS) of Samosir Regency. Meanwhile, primary data collection was obtained from direct observation in Pangururan District, Samosir Regency by conducting interviews and distributing questionnaires totalling 102 respondents. The questionnaire uses a 
Likert scale with tourists as respondents. The research framework on seasonal tourism issues can be seen in Figure 1.

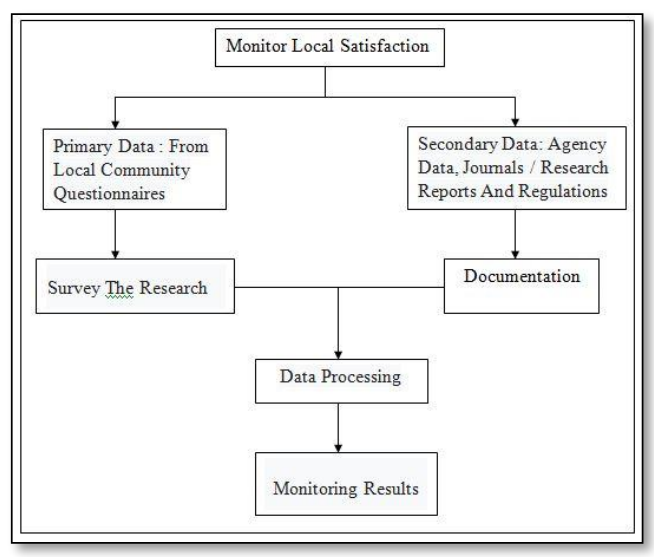

Figure 1 Methodological Framework for Seasonal Tourism Issues for Destinations

Based on observations of sustainable tourism in Pangururan District, Samosir Regency, there are 4 (four) variable components that will be monitored, namely (1) measuring the degree of seasonality; (2) strengthening the peak season and low season of tourism (increasing visits outside the tourism season); (3) provision of adequate infrastructure throughout the year; and (4) short-term jobs and seasonal jobs) contained in the variable and indicator components in this study refer to the Sustainable Tourism Observatory Monitoring Center (MCSTO) that has been established by UNWTO.

\section{$4 \quad$ Result and Discussion}

Based on the statistical results of distributing questionnaires to respondents, results were obtained that strongly agree $44 \%$ that tourists enjoy the experience at tourist destinations in Pangururan District, $44 \%$ act in agreement, 9\% are normal, 2\% disagree and 1\% strongly disagree.

\section{The Roads And Signage Make It Easy For Me}

For travelling Stating (26\%) tourists who strongly agree that the existing roads and signage make it easier for tourists to travel in Pangururan District, (47\%) agree, (24\%) say they are normal, (3\%) disagree and (0) \%) strongly disagree.

\section{This Destination Is Quiet And Not Crowded With Visitors}

Stating (23\%) strongly agree regarding calm destinations and not crowded with visitors, (46\%) agree, $(25 \%)$ say they are normal, $(6 \%)$ disagree, and $(0 \%)$ strongly disagree.

\section{Get Interesting Experiences From The Local Culture}


Stating (29\%) strongly agree regarding tourists getting interesting experiences from local culture in Pangururan sub-district, (40\%) agreeing, (27\%) saying it is normal, (2\%) disagreeing, and $(2 \%)$ strongly disagreeing agree.

\section{Existing Cultural And Natural Sites Are Well Cared For}

(24\%) strongly agree with the cultural and natural sites that are well maintained in Pangururan District, (36\%) agree, (33\%) say they are normal, (4\%) disagree, and (3\%) state totally disagree.

\section{Cultural And Natural Sites Are Easy To Access}

(24\%) strongly agree with the availability of souvenirs and artworks in Pangururan District, $(37 \%)$ agree, $(36 \%)$ say they are normal, $(2 \%)$ disagree, and (1\%) strongly disagree.

\section{Available Souvenirs And Good Works Of Art}

Stating (26\%) strongly agree regarding tourists enjoying local dishes in Pangururan District, $(41 \%)$ agreeing, (32\%) saying they are normal, (0\%) disagreeing, and (1\%) strongly disagree.

\section{Got A Chance And Enjoyed Local Dishes}

Stating (14\%) strongly agree that the quality of food is good in Pangururan District, (44\%) agree, (34\%) say it is normal, (5\%) disagree, and (3\%) strongly disagree.

\section{The Quality Of Food Here Is Good}

Stating (18\%) strongly agreed regarding the quality of good accommodation in Pangururan District, (38\%) agreed, (36\%) said it was normal, (7\%) disagreed, and (1\%) strongly disagreed.

\section{The Quality Of Accommodation Here Is Good}

Stating (13\%) strongly agree with the service that tourists feel is good in Pangururan District, $(42 \%)$ agree, $(37 \%)$ say they are normal, (6\%) disagree, and (2\%) strongly disagree.

\section{The Service I Feel Here Is Good}

Stating (22\%) strongly agree regarding staff who work in the tourism industry who are competent and very helpful in Pangururan District, (41\%) agree, (32\%) state that they are normal, (4\%) disagree, and (1\%) strongly disagree. 
(24\%) strongly agree with the availability of souvenirs and artworks in Pangururan District, (36\%) agree, (33\%) say they are normal, (4\%) disagree, and (3\%) strongly disagree.

\section{The Natural Scenery In The Destination Is Good}

Stating (38\%) strongly agree with the natural scenery that exists both in Pangururan District, (33\%) agree, (26\%) say it is normal, (2\%) disagree, and (1\%) strongly disagree.

\section{The Destination Has A Diverse And Attractive Landscape}

Stating (28\%) strongly agree regarding the destination having a diverse and attractive landscape in Pangururan District, (37\%) agreeing, (34\%) saying it is normal, (0\%) disagreeing, and (1\%) strongly disagreeing agree.

\section{Easy To Access Destinations To Visit}

Stating (25\%) strongly agree regarding easy access to destinations to visit in Pangururan District, (38\%) agree, (36\%) state that they are normal, (0\%) disagree, and (1\%) strongly disagree.

\section{Feel Safe And Comfortable During My Tour}

Stating (28\%) strongly agree regarding tourists feeling safe and comfortable while travelling in Pangururan District, (39\%) agreeing, (30\%) saying that they are normal, (2\%) disagreeing, and (1\%) stated totally disagree.

\section{Think I Got The Right Price}

Stating (24\%) strongly agree that tourists feel they get the right price in Pangururan District, $(42 \%)$ agree, $(30 \%)$ say they are normal, $(2 \%)$ disagree, and (2\%) strongly disagree.

\section{Will Recommend Destinations To My Friends}

Stating (27\%) strongly agree regarding tourists recommending destinations in Pangururan District, (49\%) agreeing, (21\%) saying they are normal, (2\%) disagreeing, and (1\%) strongly disagree.

\section{Will Come Back To This Destination Again}

Stating (18\%) strongly agree that tourists will return to destinations in Pangururan District, $(58 \%)$ agree, $(22 \%)$ say they are normal, $(1 \%)$ disagree, and (1\%) strongly disagree.

\section{Tourist Visit Rate}


In the tourism destination development sector, it is very important to pay attention to the number of tourist visits in Pangururan District, Samosir Regency. WTO (2004) states that in fact, very few destinations have consistent tourism throughout the year. Some destinations are highly dependent on climate and weather patterns. The low season reflects unfavourable weather conditions such as cold, rain, heat and excessive humidity and storms. Meanwhile, the high season with optimal weather is more favourable for the tourism sector. The number of tourist visits, both domestic and foreign tourists, is estimated to increase every year. In 2017, the number of tourist visits was 278,059 people, an increase of $45.79 \%$ of the number of tourist visits in the previous year, namely 90,728 people (Table 1 ).

Table 1 Number of Tourist Visits in Samosir Regency

\begin{tabular}{cccc}
\hline \multicolumn{4}{c}{ Number of Tourist Visits } \\
\hline Year & Domestic Tourists & International Tourists & Total \\
\hline 2013 & 124.117 & 25.662 & 149.779 \\
\hline 2014 & 140.637 & 30.450 & 171.087 \\
\hline 2015 & 141.215 & 34.248 & 175.463 \\
\hline 2016 & 154.905 & 35.823 & 190.728 \\
\hline 2017 & 222.288 & 55.771 & 278.069 \\
\hline
\end{tabular}

Based on data from BPS Samosir Regency, the level of tourist visits in the high season is January, June and December, because these three months are calendar holidays. Meanwhile, the low season occurs in September and October, where the months are the rainy season which becomes an obstacle for tourists to visit (Table 2) [8].

Table 2 The Level of Tourist Visits Every Month in 2019 in Samosir Regency

\begin{tabular}{clccc}
\hline \multirow{2}{*}{ No } & \multirow{2}{*}{ Month } & \multicolumn{2}{c}{ Regency Samosir } & \multirow{2}{*}{ Occupancy (\%) } \\
\cline { 3 - 4 } & & Archipelago Travel & Seasonal Tours & \\
\hline 1 & January & 37713 & 9021 & $68 \%$ \\
2 & February & 20642 & 4327 & $36 \%$ \\
3 & March & 25355 & 5362 & $44 \%$ \\
4 & April & 29820 & 6594 & $53 \%$ \\
5 & May & 20548 & 7168 & $40 \%$ \\
6 & June & 64074 & 9912 & $100 \%$ \\
7 & July & 19625 & 4055 & $34 \%$ \\
8 & August & 18480 & 4517 & $33 \%$ \\
9 & September & 13101 & 2407 & $22 \%$ \\
10 & October & 9212 & 1433 & $15 \%$ \\
11 & November & 17198 & 3135 & $29 \%$ \\
12 & December & 37157 & 7793 & $65 \%$ \\
\hline \multicolumn{3}{r}{ Total } & $\mathbf{3 7 8 . 6 4 9}$ & $\mathbf{4 6 \%}$ \\
\hline
\end{tabular}


As for the results of observations at 2 tourist attraction points in Pangururan District, the level of tourist visits in Pangururan District, Samosir Regency, on the attractions of Boru Sinaetang and the Ulos Batak Huta Raja Lumban Suhisuhi Weaving Community is always busy during the holiday season. It's just that because the Covid-19 pandemic has a significant impact on decreasing the level of tourist visits [16]. on the observation of the location of tourism in the Ulos Huta Raja weaving community tourist attraction and the Boru Sinaetang tourist destination in (Figure 2).

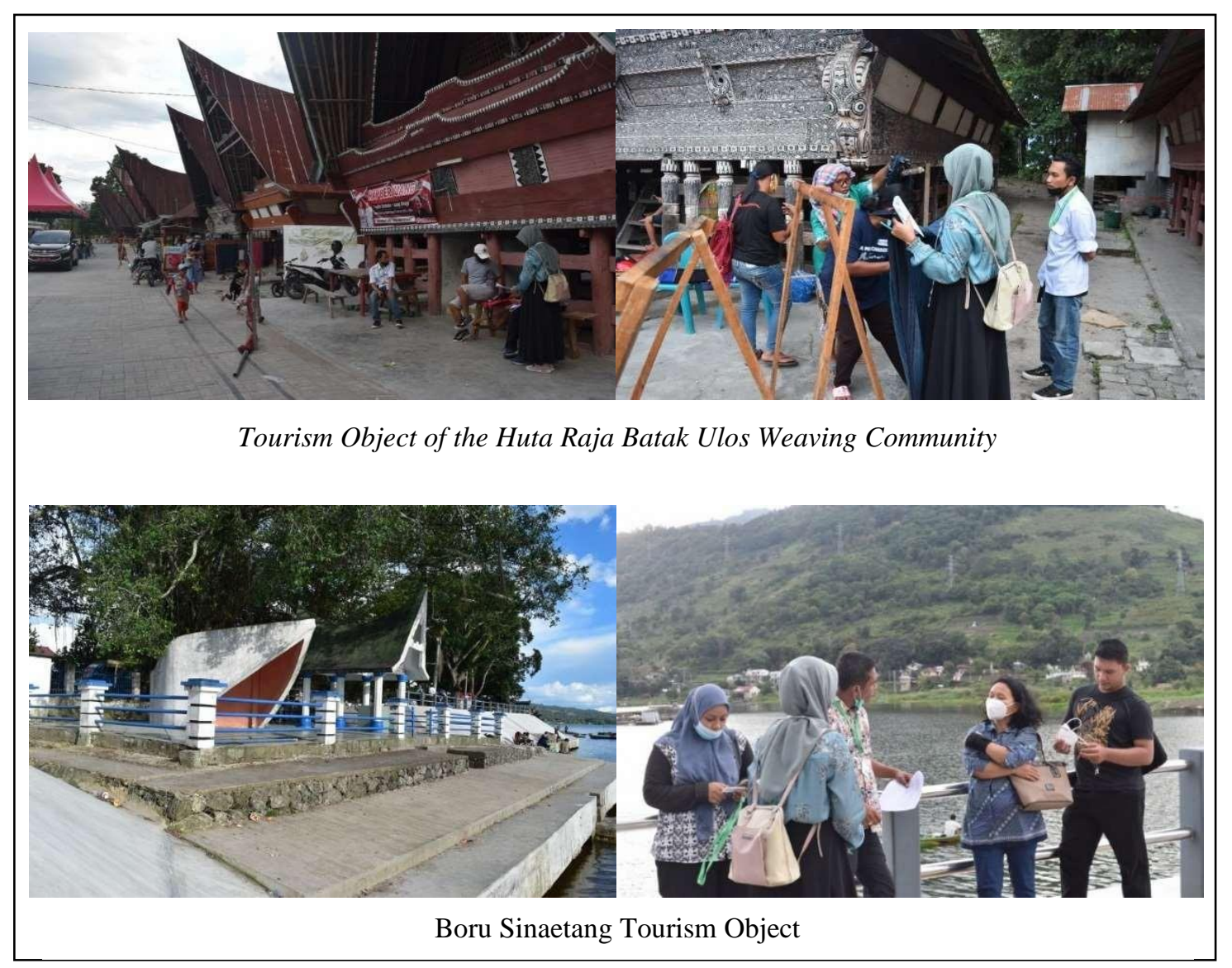

Figure 2 Tourist Attractions in Pangururan District, Samosir Regency

The picture shows the tourism attraction that occurs at Tourism Objects of the Ulos Huta Raja Batak Weaving Community and Boru Sinaetang Tourism Object in this attraction the lack of visitors is due to the Covid 19 pandemic disaster but it does not rule out the absence of visitors. What happened to the Huta Raja weaving community has just been a weaving festival held by the weaving craftsmen community, while at the new Sinaetang tourist location only a few people have visited. With a pandemic like now, visitors have experienced a drastic decline.

\section{Increase Visits Outside the Tourism Season}

Monitoring of tourist visits outside the tourist season is important because it has an impact on tourism activities. This monitoring is carried out by taking samples of tourists in Pangururan 
District, Samosir Regency. The statement table on the reasons for tourists visiting Pangururan sub-district, Samosir Regency can be seen in (Table 3).

Table 3 Levels of Monthly Tourist Visits in 2019 in Samosir Regency

\begin{tabular}{clc}
\hline & & Existing Conditions \\
\cline { 3 - 3 } No & \multicolumn{1}{c}{ Issue Components and Indicators } & $\mathbf{2 0 2 0}$ \\
\cline { 3 - 3 } & \multicolumn{1}{c}{ Reasons for tourist visits outside the tourist season } \\
\hline 1 & Enjoy the experience at the destination & Y3 \\
\hline 2 & Existing roads and signage make it easy & 4,5 \\
\hline 3 & The destination is quiet and not crowded & 3,6 \\
\hline 4 & Get interesting experiences from local culture & 3,6 \\
\hline 5 & Existing cultural and natural sites are well maintained & 4,6 \\
\hline 6 & Cultural and natural sites are easy to access & 3,6 \\
\hline 7 & There are good souvenirs and artworks available & 3,6 \\
\hline 8 & Got a chance and enjoyed local dishes & 3,6 \\
\hline 9 & Good quality of food & 3,4 \\
\hline 10 & Good quality accommodation & 3,4 \\
\hline 11 & Good service & 3,5 \\
\hline 12 & The staff who work in the tourism industry here are & 4 \\
\hline 13 & competent and very helpful & 4 \\
\hline 14 & Datural scenery in good destinations & 4,6 \\
\hline 15 & Easy to access destinations to visit & 4,6 \\
\hline 16 & Safe and comfortable during your tour & 4 \\
\hline 17 & Getting the right price & 4,3 \\
\hline 18 & Will recommend destination to friends & 4,5 \\
\hline 19 & Will return to this destination again & 4,3 \\
\hline Overall Average & $\mathbf{4 0 \%}$ \\
\hline Percentage (\%) & & 4 \\
\hline
\end{tabular}

Caption:

\begin{tabular}{lll}
\hline Range & Satisfaction Range \\
\hline $1-1,5$ & Very Dissatisfied \\
$1,6-2,5$ & Not Satisfied \\
$2,6-3,5$ & Enough \\
$3,6-4,5$ & Satisfied \\
$4,6-5$ & Very Satisfied \\
\hline
\end{tabular}

Thus, the results of monitoring the issue of tourism towards increasing visits outside the tourism season in Pangururan District from 2018 to 2020 can be seen in Table 3. From the overall statistical data above, it explains that around $80 \%$ or with an average value range of 4 tourists have a reason for a return visit outside of the tourist season. Thus, tourist destinations in Panururan District, Samosir Regency, are in a good category. 


\section{Seasonal Labour}

From the data on the level of tourist visits above, it can be estimated that the high season labour is in January, June and December which is the peak of the holiday season according to the calendar, while the low season labour is in September-October. The results of monitoring in terms of short-term work and seasonal work at tourist destinations in Pangururan District, Samosir Regency, can be seen in the method of identifying sustainable tourism performance on seasonal tourism issues. The statement table on the method for identifying sustainable tourism performance on seasonal tourism in Pangururan sub-district, Samosir Regency can be seen in (Table 4).

Table 4 The method for identifying sustainable tourism performance on seasonal tourism issues in Pangururan District, Samosir Regency

\begin{tabular}{llc}
\hline \multirow{2}{*}{ No } & Issue Components and Indicators & Existing Conditions \\
\cline { 3 - 3 } & $\begin{array}{l}\text { Percentage of employment from the tourism industry that is } \\
\text { permanent }\end{array}$ & 3.5 \\
\hline
\end{tabular}

Caption:

\begin{tabular}{lll}
\hline Range & Satisfaction Range \\
\hline $1-1,5$ & Very Dissatisfied \\
$1,6-2,5$ & Not Satisfied \\
$2,6-3,5$ & Enough \\
$3,6-4,5$ & Satisfied \\
$4,6-5$ & Very Satisfied \\
\hline
\end{tabular}

The results of monitoring the issue of tourism on the seasonal workforce for the tourism season in Pangururan District in 2020 can be seen in Table 4. From the overall data above, it explains that showing significant satisfaction or with a value range of 3.5 tourism workers has a reason for the existence of tourism activities. labour can work. Thus, tourist destinations in Panururan District, Samosir Regency, are in a good category.

\section{Conclusion}

The results of the research based on the answers of local people or newcomers explained that tourism shows an impact that will have a significant impact on regional income where with tourism, the government can increase income from tourists managed by the government and cannot be separated from tours managed by individuals which also increase income. individuals with regard to this society are helped by opening up jobs for the community. However, with the current pandemic condition, many have complained that the number of tourists has decreased so that the government and individual stages have decreased because some people are in the stages of managing tourist objects in the Pangururan sub-district, Samosir Regency. 
As for the condition that the dissatisfaction felt by managers is due to the practice of tourism only during the holiday season where there is a surge in visitors, while in fact, tourist destinations in the Pangururan sub-district are open every day, while visitors on normal days do not experience an increase in visitors. During this pandemic, the community felt very unsettling for tourism managers because the absence of visitors at the community stage had decreased. However, the impact that occurs on the environment does not cause pollution, this is because tourism management is quite good. As a form of the government's role in supporting tourism, especially in Pangururan District, Samosir Regency, infrastructure development in the form of tourist destination facilities and infrastructure so as to attract more tourists both in the holiday season and in the season of weekdays.

\section{REFERENCES}

[1] Kušen, Eduard. A System Of Tourism Attractions. Tourism Review Vol 58 No 4, 2010.

[2] Saputra, A., \& Ali, K. (2020). Analysis of Tourism Policy on Management of Tourism Objects in Samosi Regency. Dharmawangsa News, 14(4), 564-584.

[3] Mahulae, P. J. M. (2019). Problem Description Of Sustainable Tourism Development Effort On Toba Lake North Sumatera. Innovation, 16(1), 11-20.

[4] Mardiastuti, A., et al. (2014). Democratic Governanc Based Tourism Development Policy. Surabaya: Pustaka Radja

[5] Noel B. Salazar, Yang Zhang (2013). TOURISM Season Lifestyle: Elite Chinese Case. https://doi.org/10.1016/j.annals.2013.04.002

[6] Yu-Wei Chang, Meng-Yuan Liao. (2010). An ARIMA Seasonal Tourism Forecasting Model: The Case of Taiwan. Asia Pacific Journal of Tourism Research. https://doi.org/10.1080/10941661003630001

[7] Pham, K., Andereck, K., \& Vogt, C. (2019). Local residents' perceptions about tourism development.

[8] Jorge Ridderstaat, Marck Oduber, Robertico Croes, Peter Nijkamp, Pim Martens. (2014). The impact of seasonal patterns of climate on repeated fluctuations in tourism demand: Evidence from Aruba. https://doi.org/10.1016/j.tourman.2013.09.005

[9] Rivera, M., Croes, R., \& Lee, S. H. (2016). Tourism development and happiness: A residents' perspective. Journal of Destination Marketing \& Management, 5(1), 5-15.

[10] Sanchez del Rio-Vazquez, M. E., Rodríguez-Rad, C. J., \& Revilla-Camacho, M. Á. (2019). Relevance of social, economic, and environmental impacts on residents' satisfaction with the public administration of tourism. Sustainability, 11(22), 6380.

[11] Mauro Ferrante, Giovanni L. Lo Magno, Stefano De Cantis. (2018). Measuring tourism seasons in European countries. Tourism Management. 220235.https://doi.org/10.1016/j.tourman.2018.03.015

[12] Woo, E., Kim, H., \& Uysal, M. (2015). Life satisfaction and support for tourism development. Annals of tourism research, 50, 84-97. 
[13] Liao, C. C., Lin, Y. X., \& Hsieh, H. H. (2019). Satisfaction of Indigenous Tourism from Residents' Perspective: A Case Study in Nantou County, Taiwan. Sustainability, 11(1), 276.

[14] Bigović, M. (2011) Mengukur musim dalam pariwisata: Sebuah studi kasus dari Montenegro, Academica Turistica. Jurnal Pariwisata \& Inovasi , 4 (2): 15-32 